\title{
Comparison of Techniques to Sample Xanthomonas axonopodis pv. citri in Windblown Spray
}

\author{
P. E. Parker, USDA, APHIS, PPQ, CPHST, Pest Detection Diagnostics and Management Laboratory, Moore Air \\ Base, 22675 N. Moorefield Rd., Edinburg, TX 78541; and C. H. Bock and T. R. Gottwald, USDA-ARS-USHRL, \\ 2001 S. Rock Rd., Ft. Pierce, FL 34945
}

\begin{abstract}
Parker, P. E., Bock, C. H., and Gottwald, T. R. 2005. Comparison of techniques to sample Xanthomonas axonopodis pv. citri in windblown spray. Plant Dis. 89:1324-1330.

Four techniques were evaluated to sample windblown splash from canker-infected citrus plants. Two volumetric cyclone samplers (PAS450 and Burkard Cyclone) and two passive samplers (funnels and panels) were evaluated. The PAS450 collected no detectable bacteria in any trial. The Burkard cyclone consistently collected spray, but was found to do so even when the power was turned off. Thus, the Burkard cyclone essentially functioned passively, negating the advantage of a volumetric sampler for this application. Panels collected the greatest volume of splash followed by funnel samplers. CFU of Xanthomonas axonopodis pv. citri per ml collected were significantly different between Burkards and panel samplers, but panels and funnels collected similar concentrations (Burkards, funnels, and panels collected 1,182, 1,426, and 2,667 CFU per $\mathrm{ml}$, respectively). Positive correlations were found between the volume and the total $X$. axonopodis pv. citri collected, and between CFU per $\mathrm{ml}$ and total collected for panel and funnel samples. However, there was no correlation between $\mathrm{CFU}$ per $\mathrm{ml}$ and volume collected for either sampler. The Burkard sample showed a strong positive correlation $(P<0.01)$ between volume collected, total number of $X$. axonopodis pv. citri collected, and CFU per ml. The CFU per ml collected by the panels and funnels were similar (coefficient of determination, $R^{2}=0.97$ ), compared with the relationship between the Burkard and panel catches $\left(R^{2}=0.68\right)$, or between the Burkard and funnel catches $\left(R^{2}=0.62\right)$. Panels collected the greatest volume, and effectively collected bacteria-laden windblown splash. The greater sampling area of the panels allowed a more representative sample than the other methods tested.
\end{abstract}

Citrus canker, caused by Xanthomonas axonopodis pv. citri, is a plant-pathogenic bacterial disease that infects and causes severe damage to citrus crops $(12,18)$. The disease occurs in many citrus-growing regions of the world, and its recent introduction to Florida has created difficulties with international trade and movement of plant material from regulated areas. To protect the financial interests of the citrus industry in Florida, eradication of the pathogen has been deemed a necessity (18) and is currently underway.

Windborne rain splash disperses many plant-pathogenic bacteria; the first experiments indicating rain splash dispersal of bacterial pathogens were published in 1917, and several examples of bacterial dispersal have been described subsequently $(1,3,5)$. Larger splash droplets generally fall close to the inoculum source, but smaller droplets and aerosols produced

Corresponding author: P. E. Parker

E-mail: paul.e.parker@aphis.usda.gov

Accepted for publication 20 July 2005 .

DOI: 10.1094/PD-89-1324

This article is in the public domain and not copyrightable. It may be freely reprinted with customary crediting of the source. The American Phytopathological Society, 2005. by raindrop impact on diseased foliage are also implicated in the longer distance spread $(5,13,15)$. Aerosol dispersal of $X$. axonopodis pv. citri has been observed in chipping of canker-infected trees $(14,17)$. Furthermore, splash is known to cause dispersal of $X$. axonopodis pv. citri (16), and there is evidence that wind is also involved $(19,20,22)$. However, techniques to sample windborne splash have not been compared or evaluated for effectiveness at collecting splash or spray containing bacteria of $X$. axonopodis pv. citri. During rainstorms, citrus canker lesions exude abundant quantities of $X$. axonopodis pv. citri immediately following leaf wetting $(16,19,23)$. Subsequent splash onto nearby foliage disperses $X$. axonopodis pv. citri and can cause new infections (16). Wind dispersal of bacteria-laden splash and spray can transport the pathogen further $(19,20)$, and when strong winds occur, as in tropical storms in Florida, the distance could be up to several miles. Strong winds were most likely responsible for several new outbreaks of citrus canker that developed subsequent to Tropical Storm Jerry in south Florida in August 1995 (6). Furthermore, analysis of the spatial distribution of canker-infected plants suggests the combined effect of wind and rain splash are responsible for spreading citrus canker disease (2,6-9). However, there is little information on the dynamics of the dispersal process of the pathogen in windblown spray (19). Prior to an investigation of these dynamics, a comparison of various sampling methods must be made under conditions of windblown splash to determine the most effective sampling technique.

Various passive and volumetric samplers have been used to sample air- or splashborne propagules $(11,14,21)$, including horizontal or vertical surfaces such as microscope slides, funnels, or panels and volumetric samplers, including the Burkard and Andersen samplers. Hunter and Kunimoto (11) used vertical panels to sample sporangia of Phytophthora palmivora in wind-driven rain splash, but to our knowledge this method has not been compared with other samplers.

Information on the nature and role of wind and splash on the dispersal of $X$. axonopodis pv. citri bacteria will contribute to our understanding of the epidemiology of citrus canker; this, in turn, will contribute to a rational and informed basis for eradication and management of citrus canker in endemic areas. In this report, we describe experiments that compared the effectiveness of four sampling techniques for collecting bacteria of $X$. axonopodis pv. citri downwind of infected citrus canker plants subject to water splash and wind, and we use this as a basis for choosing the most effective collecting device for use in further experiments investigating dispersal of $X$. axonopodis pv. citri in windblown splash.

\section{MATERIALS AND METHODS}

Source plants. In each experiment, a group of five Duncan grapefruit (Citrus paradisi) plants was used as a source of inoculum. The trees were approximately $1.5 \mathrm{~m}$ tall with crowns approximately $0.8 \times$ $0.8 \mathrm{~m}$, and had 41 to 205 leaves, with disease severity ranging from 5.6 to 25.6 lesions per infected leaf and an incidence of 76.8 to $87.8 \%$ leaves infected.

Producing wind and rain splash. Water splash and wind were generated using a combination of yard-blowers (Leaf Hog, model BV2500, Black \& Decker, Towson, $\mathrm{MD}$ ) and garden sprayer nozzles (Orbit/Sunmate 7 Pattern Zinc Pistol Nozzles, Orbit Irrigation Products, Inc., Bountiful, UT). The yard-blowers produce a maximum wind speed of $320 \mathrm{kph}$ at the outlet. 
Three yard-blowers were mounted to a frame placed on a cart with the outlets 107 $\mathrm{cm}$ aboveground and the cross- and downwind profiles characterized (Fig. 1). Wind speeds projected at $1 \mathrm{~m}$ were $>12 \mathrm{~m} / \mathrm{s}$, although the wind speed dropped with distance to $4.5 \mathrm{~m} / \mathrm{s}$ at $6 \mathrm{~m}$. (Due to the surrounding still air, a gradient in wind speed is inevitable, even over short distances.) Three sprayers were attached to a PVC pipe and linked to the frame below the blowers with the orifices pointed up into the air stream, such that the water spraying from the nozzle entered the wind stream and was blown downwind. The sprayers were set to the "jet" option to produce the most desirable range of droplet sizes. The PVC pipe was linked to a water source from a local well. The nozzles each delivered ca. 4.5 liters/min (68 liters in $15 \mathrm{~min}$ ), which was checked by taking samples and measuring the time taken to achieve a measured volume. Well water was sampled and plated. No $X$. axonopodis pv. citri were present in the water source.

Sampler types and experiment design. The efficiency of sampling was compared for four sampling methods: two volumetric samplers, the PAS 450 (Camber Corporation, Huntsville, AL) and the Burkard Cyclone Sampler (Burkard Manufacturing Co., Rickmansworth, England), and two passive samplers, Plexiglas panels (11; Fig. 2 ) and funnels. The PAS 450 uses a mixture of sterile water plus surfactant in a cyclonic chamber to capture bioaerosols. The airflow into the sampler is 450 liters $\mathrm{min}^{-1}$. The Burkard cyclone sampler relies solely on a cyclonic airflow from which bioaerosols settle into a collection tube. Airflow into the sampler is 16.5 liters $\mathrm{min}^{-1}$. The passive samplers both relied on spray impinging on the surface. The panel area was $1,176 \mathrm{~cm}^{2}$ and was 131-fold larger in collection area than the funnels. The funnel collection area was $9 \mathrm{~cm}^{2}$, and they were set at an angle of ca. $50^{\circ}$ toward the source of windblown spray. In both passive samplers, the splash collected was directed into a sample vessel for further processing. Each experiment was run for 15-min periods. The volume of the sample was measured, and each sample was subject to dilution plating on the semi-selective medium $\mathrm{KCB}$ (10), consisting of nutrient agar (NA) amended with kasugamycin $\left(16 \mathrm{mg} \mathrm{liter}^{-1}\right)$, cephalexin (35 mg liter ${ }^{-1}$, and the fungicide Bravo 720 Flowable (12 mg of chlorothalonil liter $\left.^{-1}\right)$. After incubation at $27^{\circ} \mathrm{C}$ for 5 to 6 days, the plates were examined and the total quantity of $X$. axonopodis pv. citri captured was determined. In addition to the splash samples, the well water used to generate the splash and aerosols was plated out as a control. The well water was also used to wash the panels prior to the collection of bacteria.

In the first experiment, the sampling ability of the PAS 450 was compared with that of the Burkard Cyclone sampler. Both samplers were set up $1 \mathrm{~m}$ downwind of the source of inoculum immediately next to each other and at the same height $(1.2 \mathrm{~m})$, and the blower/sprayer apparatus was located $1 \mathrm{~m}$ upwind from the trees. The experiment was repeated three times.

In the second experiment, the Burkard, panels, and funnels were compared. The samplers were set immediately adjacent to each other at the same height $(1.2 \mathrm{~m})$. In this experiment, the samplers were spaced at 1,4 , and $10 \mathrm{~m}$ distance from the inoculum source to determine how efficient each sampler was at capturing spray droplets at various distances from the source of inoculum. The distance between the blower/ sprayer apparatus and the trees was the same as for the previous experiment. The experiment was set up on a NNE-SSW axis based on the wind direction when the experiment was conducted, with the blowers pointing toward the NNE (wind pre- dominately from SSW). This experiment was also repeated three times. During the course of this study, it was observed that the Burkard Cyclone samplers collected spray whether or not the device was energized, so a third experiment was designed where the Burkards were tested alone to compare the samples collected with and without power.

Wind speed and direction were monitored using a cup anemometer and a wind vane, respectively, and temperature was recorded using a temperature sensor (Davis Instruments, Hayward, CA). One weather station was placed immediately upwind of the trees, a second just downwind of the canopy, a third at $4 \mathrm{~m}$ downwind, and a fourth at $10 \mathrm{~m}$ downwind from the canopy.

Data analysis. The data were analyzed using Microsoft Excel 2000 and SAS V8.0 (SAS Systems, Cary, NC). An analysis of variance (ANOVA) was performed using

\section{A}

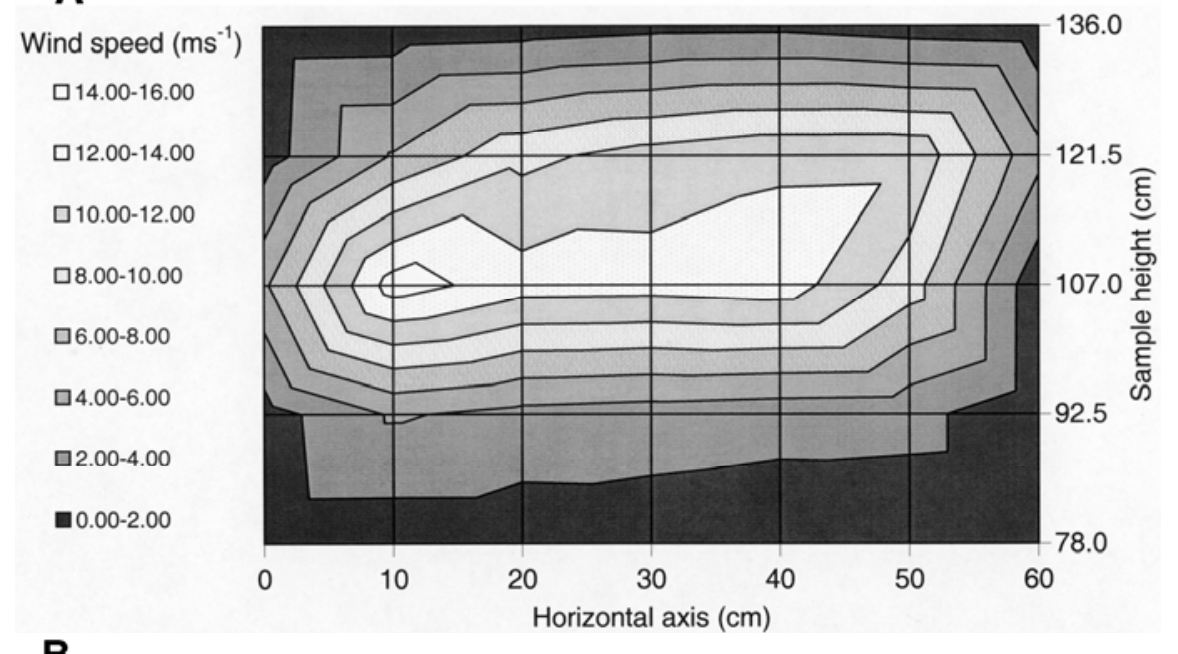

B

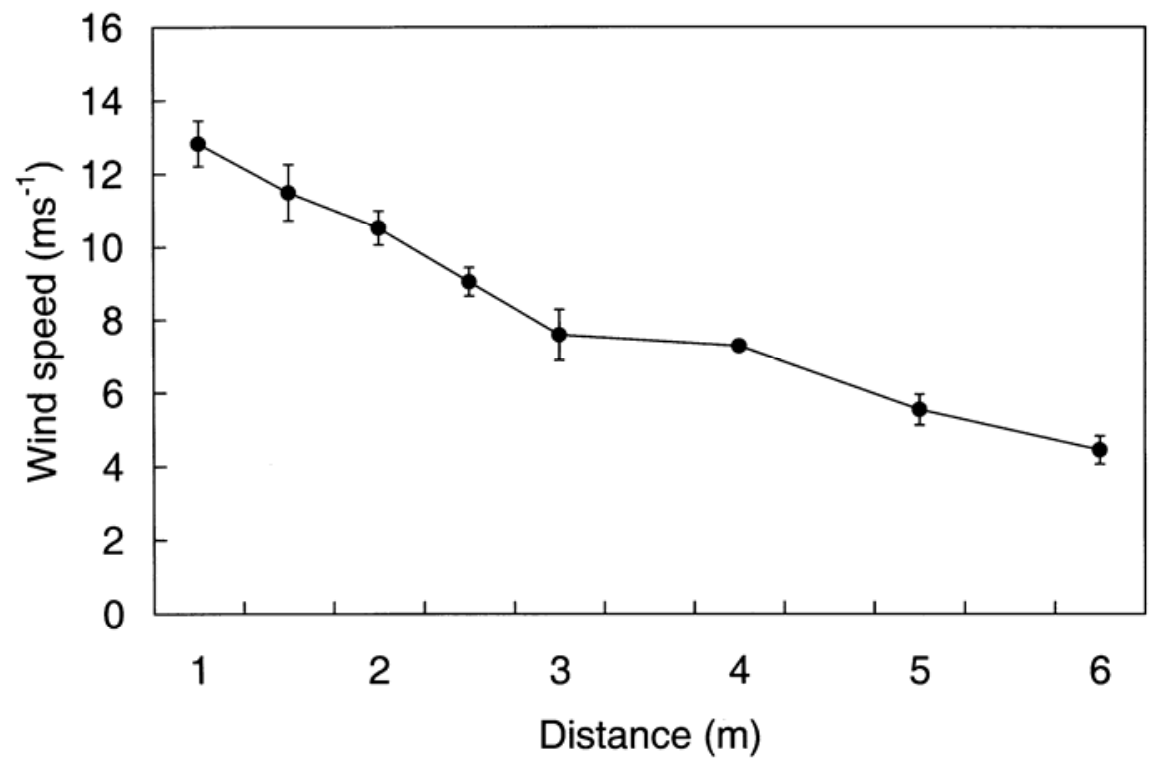

Fig. 1. Crosswind (A) and downwind (B) profiles measured for the three yard-blowers used to generate wind to investigate dispersal of bacteria of Xanthomonas axonopodis pv. citri in wind-driven splash downwind from canker-infected grapefruit trees. 
the General Linear Models procedure to investigate the effect of distance and sampler type on the volume, concentration of $X$. axonopodis pv. citri, and total $X$. axonopodis pv. citri collected (data were log-transformed to reduce the heterogene- ity of variance). Because no measurable spray was recorded at $10 \mathrm{~m}$, this position was omitted from the analysis of CFU per $\mathrm{ml}$ of collected splash and volume collected. A post hoc means comparison was done using Tukey's HSD test for single

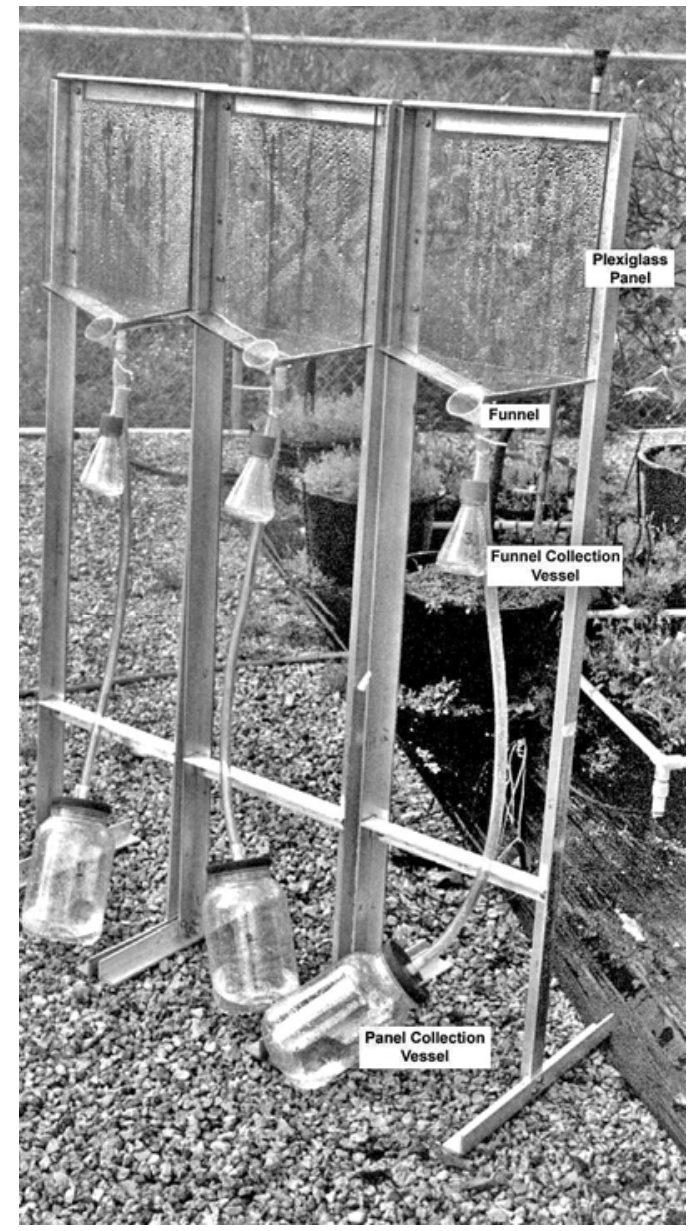

Fig. 2. Panels and funnels used to collect wind-dispersed spray downwind from canker-infected grapefruit plants.

Table 1. Volume of spray and number of bacteria of Xanthomonas axonopodis pv. citri collected using various sampling devices to collect windblown splash at different distances downwind from cankerinfected citrus plants

\begin{tabular}{lcccc}
\hline Sampler & Distance $(\mathbf{m})$ & Volume $^{\mathbf{a}}(\mathbf{m l})$ & Mean CFU/ml & Bacteria population \\
\hline Panels & 1 & $3,032(3.48)$ & $4,611(3.58)$ & $1.5 \times 10^{7}(7.06)$ \\
& 4 & $272(2.41)$ & $3,388(3.39)$ & $1.1 \times 10^{6}(5.80)$ \\
& 10 & $0(0)$ & $0(0)$ & $4.4 \times 10^{2}(1.84)$ \\
Funnels & Mean & $1,651(2.95)$ & $4,000(3.49)$ & $5.32 \times 10^{6}(4.90)$ \\
& 1 & $151(2.16)$ & $2,300(3.25)$ & $4.2 \times 10^{5}(5.41)$ \\
& 4 & $15(1.17)$ & $1,978(3.23)$ & $3.3 \times 10^{4}(4.40)$ \\
Burkards & 10 & $0(0)$ & $0(0)$ & $3.3 \times 10^{1}(1.11)$ \\
& Mean & $83(1.67)$ & $2,138(3.24)$ & $1.49 \times 10^{5}(3.64)$ \\
& 1 & $9(0.95)$ & $1,556(3.19)$ & $1.4 \times 10^{4}(4.14)$ \\
Mean distance & 4 & $10(0.98)$ & $1,989(3.20)$ & $2.4 \times 10^{4}(4.18)$ \\
& 10 & $0(0)$ & $0(0)$ & $2.3(0.27)$ \\
& 1 & $10(0.97)$ & $1,772(3.19)$ & $1.26 \times 10^{4}(2.86)$ \\
SED & 4 & $99(1.52)$ & $2,822(3.34)$ & $5.1 \times 10^{6}(5.53)$ \\
SED distance & 10 & $0(0)$ & $0(0)$ & $3.7 \times 10^{5}(4.79)$ \\
SED samplers $\times$ distance & & $388(1.24)$ & $1,759(2.20)$ & $1.6 \times 10^{2}(1.08)$ \\
\hline
\end{tabular}

\footnotetext{
${ }^{a}$ Log transformed data in parentheses.

${ }^{\mathrm{b}}$ Standard error of the difference between the means.
}

factors and interactions (distance, sampler type, and replicate), and standard errors of the differences between various treatment means were generated. The effect of wind direction on volume collected during each replicate was investigated with correlation analysis. Wind direction was quantified by giving a score of 5 to the wind direction aligned with the blower axis (NNE-SSW) when the experiment was established. Wind direction ranged from SSW to ESE, with ESE having a score of 1 (the greatest negative impact on spray direction in relation to axis orientation of the panels). Thus, one point less was given to wind coming from each $22.5^{\circ}$ deviation from the NNE-SSW blower axis. This number was then multiplied by the percentage of time the wind blew from that direction during the collecting period, and the resulting numbers were summed to produce a weighted total for each replicate. A Pearson's correlation analysis was subsequently performed to explore association between the percentage of total volume collected in each replicate for each sampler and wind direction. In addition, to investigate association between total $X$. axonopodis pv. citri, volume, and concentration for and between each of the sampler types, a Pearson's correlation analysis was performed between all variables. Linear regression analysis was subsequently used to investigate the relationship between the $\mathrm{CFU}$ of $X$. axonopodis pv. citri per $\mathrm{ml}$ caught by the panels, funnels, and Burkard cyclone samplers and the similarity between samples assessed based on the coefficient of determination.

\section{RESULTS}

The wind speed differed depending on whether it was measured upwind or downwind of the infected plants, but was fairly constant at each location over the 15min sampling period. At no time during the first experiment did the PAS 450 collect any bacteria in any test. In contrast, the Burkard sampled up to $21,400 X$. axonopodis pv. citri bacteria per $\mathrm{m}^{3}$ of air in the splash collected (data not shown).

In the second experiment, the Burkard cyclone samplers, panel samplers, and funnels all collected windblown splash from the infected trees. ANOVA $(F=875$, $P<0.0001)$ showed the panels collected the greatest volume of splash (Table 1). The volume decreased rapidly with distance from the source for all sampler types. At $10 \mathrm{~m}$, no sampler collected a discernable volume, but washes of sampler surfaces revealed that $X$. axonopodis pv. citri bacteria were impinged on the sampler surface. Burkard samplers consistently collected the smallest volume of sample (Burkards and panels collected a mean of 6 $\mathrm{ml}$ and $1,101 \mathrm{ml}$, respectively). ANOVA ( $F$ $=8.5, P=0.0363$ ) showed that the concentration of $X$. axonopodis pv. citri collected was different among samplers (Burkards, 


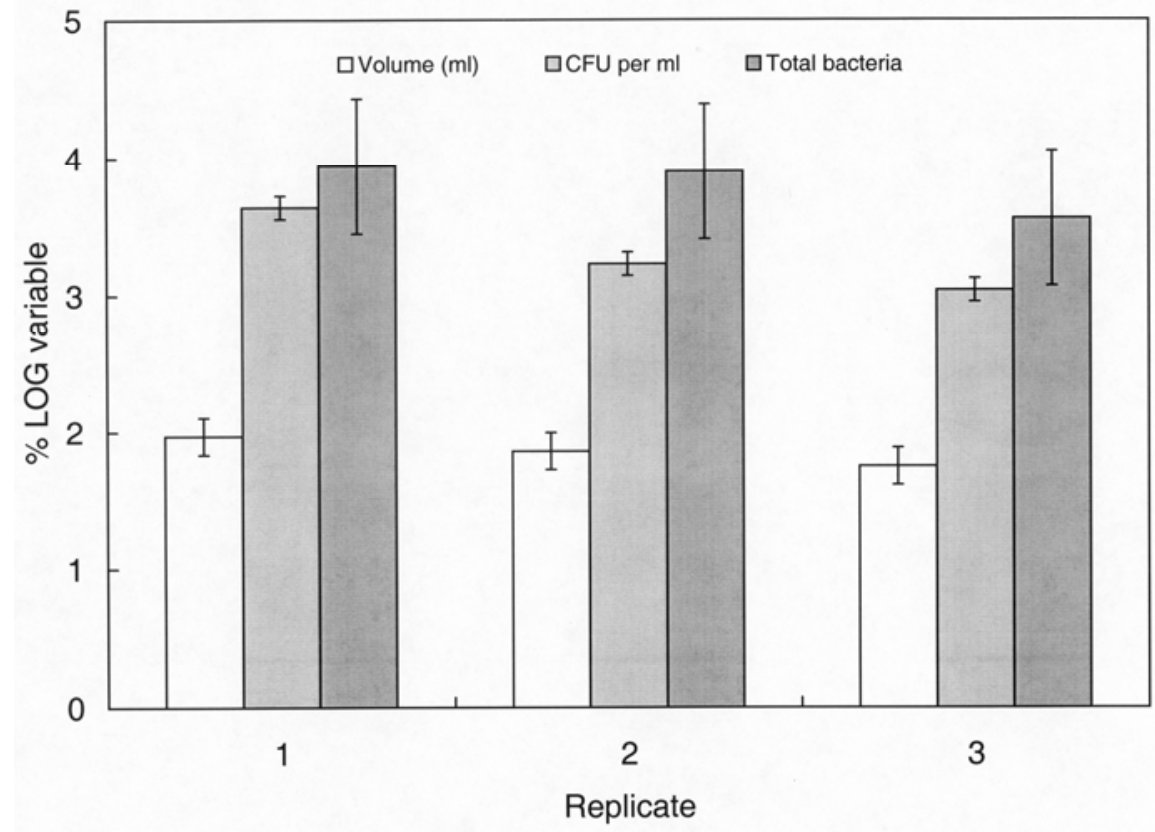

Fig. 3. Volume of splash, concentration (CFU), and total number of bacteria of Xanthomonas axonopodis pv. citri collected during three separate replicates downwind from canker-infected grapefruit trees. Least significant difference is indicated for each variable.

Table 2. Wind speed and proportion of time that wind blew from different directions during 15-min sampling periods when bacteria of Xanthomonas axonopodis pv. citri were collected downwind from canker-infected citrus plants for each replicate of the experiment

\begin{tabular}{|c|c|c|c|c|c|c|c|}
\hline \multirow{2}{*}{$\begin{array}{l}\text { Trial } \\
\text { number }\end{array}$} & \multicolumn{5}{|c|}{ Wind directiona (\% of time) } & \multicolumn{2}{|c|}{ Wind speed } \\
\hline & SSW & $\mathbf{S}$ & SSE & SE & ESE & Mean & Mean max. \\
\hline 1 & 40 & 20 & 40 & 0 & 0 & 4.6 & 7.4 \\
\hline 2 & 0 & 40 & 40 & 20 & 0 & 6.3 & 10.2 \\
\hline 3 & 0 & 20 & 47 & 13 & 20 & 5.5 & 8.8 \\
\hline
\end{tabular}

${ }^{a}$ Wind direction was quantified by giving a score of 5 to the wind direction aligned with the blower axis (NNE-SSW) when the experiment was set up. ESE had a score of 1 (the greatest negative impact on spray direction in relation to axis orientation of the panels); thus, one point less was given to wind coming from each $22.5^{\circ}$ deviation from the NNE-SSW blower axis. This number was subsequently multiplied by the percentage of time the wind blew from that direction during the collecting period, and the resulting numbers were summed to produce a weighted total for each replicate for use in further analysis. funnels, and panels collecting means of $1,182,1,426$, and 2,667 per $\mathrm{ml}$, respectively); the panels collected significantly more than the Burkards, but were not significantly different from the funnels. Distance did not affect CFU per ml collected for any sampler, but lack of splash droplets at greater distances precluded taking CFU estimates. Total $X$. axonopodis pv. citri declined with distance with all three samplers $(F=96.8, P<0.0001)$.

The experiment repeats had a significant effect on volume of spray collected $(F=$ $10.71, P=0.0248)$ and CFU of $X$. axonopodis pv. citri per $\mathrm{ml}(F=32.5, P=$ $0.0034)$ but did not affect the total $X$. axonopodis pv. citri collected in the different trials (Fig. 3). The wind direction veered from SSW to SSE in the first replicate and from S to SSE by the third replicate (Table 2). However, the layout of the experiment was not altered during this period. Thus, the plume of windblown spray was blown more toward the west with the latter two experiment repeats and explains the generally lower volumes collected with each consecutive replicate. There was a positive correlation between wind direction and volume of spray collected $(r=0.9317, P<0.0001)$.

The correlations between variables may be divided into those related to individual sampler types, and comparisons made between the variables related to different sampler types (Table 3). First, within sampler correlations showed both panels and funnels had a positive correlation between the volume collected and the total $X$. axonopodis pv. citri collected, and between concentration of the pathogen and the total collected, but there was no correlation between concentration of $X$. axonopodis pv. citri and volume collected for either sampler. The Burkard sample showed a strong positive correlation

Table 3. Correlations between volume collected, concentration of bacteria of Xanthomonas axonopodis pv. citri per ml, and total bacteria for the sampling devices used to collect windblown spray downwind from canker-infected citrus plants

\begin{tabular}{|c|c|c|c|c|c|c|c|c|c|c|}
\hline \multirow[b]{3}{*}{$\begin{array}{l}\text { Sampling } \\
\text { device }\end{array}$} & \multirow[b]{3}{*}{$\begin{array}{l}\text { Sample } \\
\text { parameter }\end{array}$} & \multicolumn{9}{|c|}{ Sampling device } \\
\hline & & \multicolumn{3}{|c|}{ Panels } & \multicolumn{3}{|c|}{ Funnels } & \multicolumn{3}{|c|}{ Burkards } \\
\hline & & $\begin{array}{l}\text { Volume } \\
(\mathrm{ml})\end{array}$ & $\begin{array}{l}\text { Concentration } \\
\text { (bacteria/ml) }\end{array}$ & $\begin{array}{c}\text { Total } \\
\text { bacteria } \\
\text { collected }\end{array}$ & $\begin{array}{l}\text { Volume } \\
\text { (ml) }\end{array}$ & $\begin{array}{c}\text { Concentration } \\
\text { (bacteria/ml) }\end{array}$ & $\begin{array}{c}\text { Total } \\
\text { bacteria } \\
\text { collected }\end{array}$ & $\begin{array}{l}\text { Volume } \\
(\mathrm{ml})\end{array}$ & $\begin{array}{c}\text { Concentration } \\
\text { (bacteria/ml) }\end{array}$ & $\begin{array}{c}\text { Total } \\
\text { bacteria } \\
\text { collected }\end{array}$ \\
\hline \multirow[t]{3}{*}{ Panels } & Volume (ml) & & & & & & & & & \\
\hline & $\begin{array}{r}\text { Concentration } \\
(\text { bacteria/ml) }\end{array}$ & 0.5711 & & & & & & & & \\
\hline & $\begin{array}{l}\text { Total bacteria } \\
\text { collected }\end{array}$ & $0.8229 * * a$ & $0.7616^{*}$ & & & & & & & \\
\hline \multirow[t]{3}{*}{ Funnels } & Volume (ml) & $0.9780 * * *$ & 0.6603 & $0.9169 * * *$ & & & & & & \\
\hline & $\begin{array}{r}\text { Concentration } \\
(\text { bacteria/ml) }\end{array}$ & 0.5296 & $0.9871 * * *$ & $0.7608^{*}$ & 0.6314 & & & & & \\
\hline & $\begin{array}{l}\text { Total bacteria } \\
\text { collected }\end{array}$ & $0.7459 *$ & $0.7632 *$ & $0.9918 * * *$ & $0.8593 * *$ & $0.7745^{*}$ & & & & \\
\hline \multirow[t]{3}{*}{ Burkards } & Volume (ml) & 0.4669 & $0.7870^{*}$ & 0.3976 & 0.4615 & $0.7965^{*}$ & 0.3685 & & & \\
\hline & $\begin{array}{r}\text { Concentration } \\
\text { (bacteria/ml) }\end{array}$ & 0.3042 & $0.8221 * *$ & 0.2986 & 0.3207 & $0.7863^{*}$ & 0.2761 & $0.8995 * * *$ & & \\
\hline & $\begin{array}{l}\text { Total bacteria } \\
\text { collected }\end{array}$ & 0.1364 & $0.7699 *$ & 0.1852 & 0.1595 & $0.7283^{*}$ & 0.1786 & $0.8057 * *$ & $0.9746 * * *$ & \\
\hline
\end{tabular}

a $*, P \leq 0.05 \% ; * *, P \leq 0.01 \% ; * * *, P \leq 0.001 \%$. 


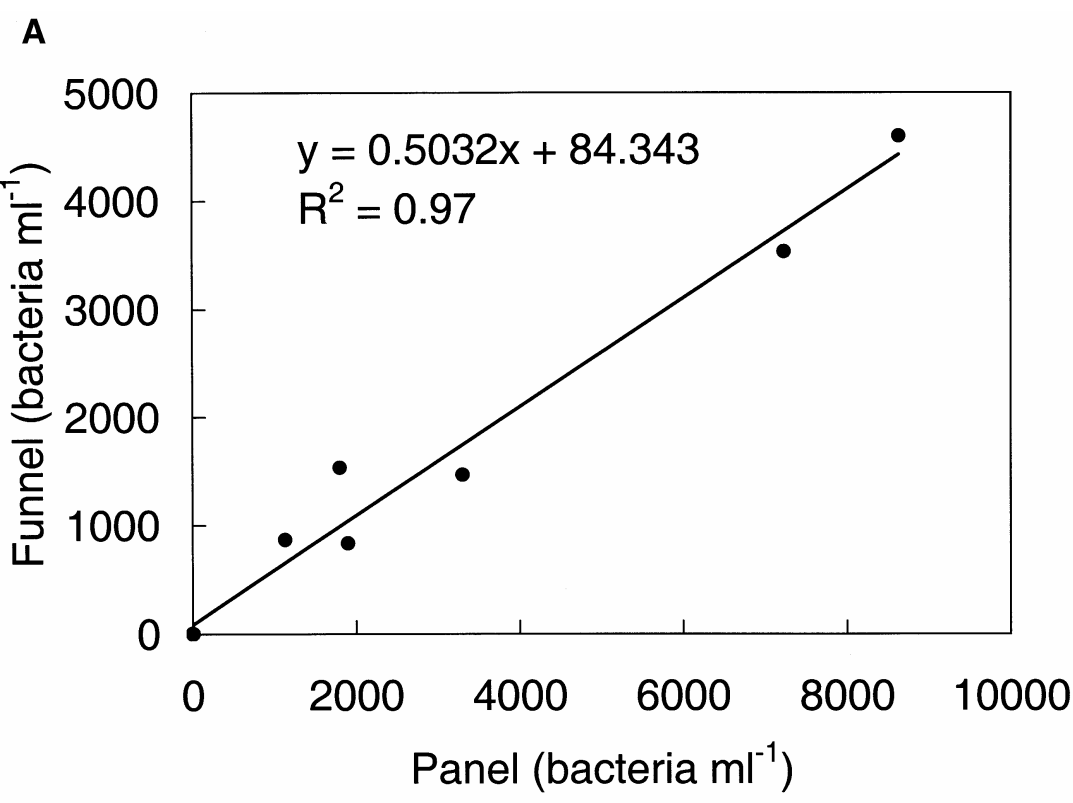

B

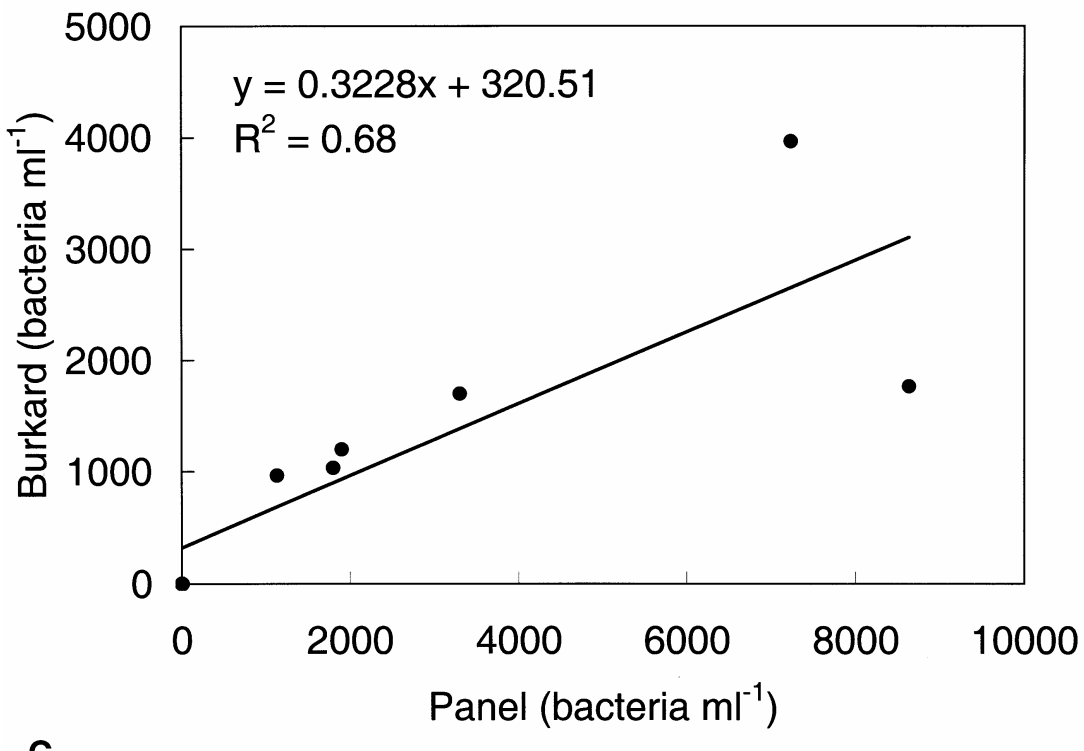

C

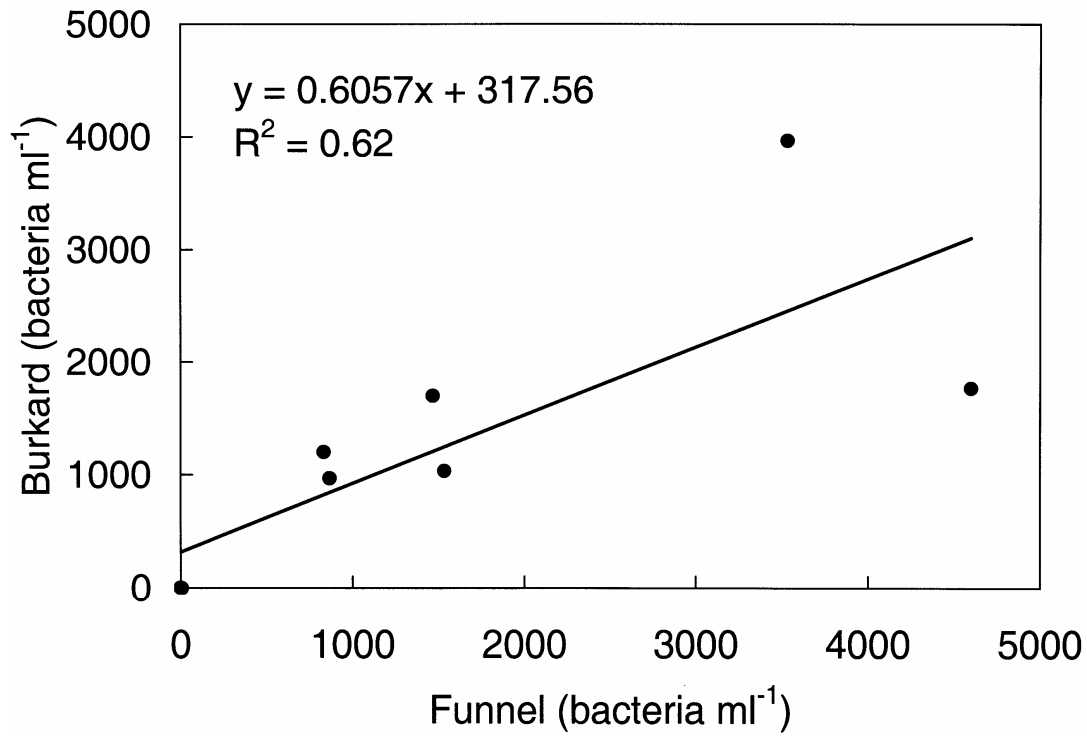

Fig. 4. Relationship between number of bacteria of Xanthomonas axonopodis pv. citri collected per $\mathrm{ml}$ by the Burkard, panel, and funnel samplers.
$(P<0.01)$ between all three variables of volume collected, the total quantity of $X$. axonopodis pv. citri collected, and concentration, indicating the Burkards collected samples that varied in concentration depending on the volume collected. Second, correlations between variables from the different samplers show a significant positive relationship between all parameters except concentration of $X$. axonopodis pv. citri and volume from the panel or funnel samplers. There was a strong positive correlation between panel and funnel catches for total volume collected $(r=0.9780, P<$ 0.001 ) and $X$. axonopodis pv. citri per $\mathrm{ml}$ ( $r=0.9871, P<0.001)$; although the number of $X$. axonopodis pv. citri per $\mathrm{ml}$ collected by the Burkard was correlated with both panel $(r=0.8221, P \leq 0.01)$ and funnel $(r=0.7863, P \leq 0.05)$ catches, the total volume was not $(r=0.1852$, ns, and $r=$ 0.1786 , ns, respectively). Indeed, volume collected and total $X$. axonopodis pv. citri collected for both the panels and funnels were not correlated with any of the variables for the Burkard sampler.

The relationship between the CFU of $X$. axonopodis pv. citri per $\mathrm{ml}$ collected by each of the samplers shows that the samples collected by the panels and funnels were more similar to each other than to the volumetric Burkard sampler, as indicated by the correlation coefficient (Fig. 4A). The relationship between the Burkard catches and the panel (Fig. 4B) and funnel (Fig. 4C) catches showed that the CFU per $\mathrm{ml}$ estimated by the Burkard differed from that estimated by the panels and funnels.

In the third experiment (data not shown), Burkard samplers collected windblown splash regardless of whether the power was on or off, although power increased the sample size, volume, and total number of $X$. axonopodis pv. citri collected.

\section{DISCUSSION}

Panels were most effective at collecting $X$. axonopodis pv. citri in wind-driven splash. Panels caught a greater volume of spray and had the greatest quantity of the pathogen overall. In this experiment, a larger spray sample was found to increase the chance of finding a minimal level of $X$. axonopodis pv. citri. The funnels also appeared to be effective, but the volume of the sample was less than that collected by the panels and reflected the surface area of the sampling plane of the funnel. This could possibly be mitigated by using larger funnels, which would collect more spray. Indeed, the relationship between the panels and funnels was closest for all parameters, although presumably as panels are larger they collect a more representative sample. Hunter and Kunimoto (11) also found panels effective for collecting microorganisms in windblown rain, although they did not compare them to other methods of sample collection. No $X$. axonopodis pv. 
citri were detected with the PAS 450. The Burkard samplers collected spray whether the electric power source was on or off; it may be that they were being "force-fed" rain splash by the wind and were thus not operating volumetrically under the experimental conditions of this study. This would negate any advantages that might occur from relationships found between spray or splash collected and volume of air.

$X$. axonopodis pv. citri bacteria were collected in large quantities immediately at the beginning of the experiment, and this confirms previous observations that these bacteria are produced and dispersed in large numbers when rainfall events occur $(16,21,23)$. The volume of spray being blown through the foliage was substantial (approximately 13.5 liters $\mathrm{min}^{-1}$ ), resulting in collection of samples containing up to $8,633 \mathrm{X}$. axonopodis pv. citri per $\mathrm{ml}$ by the panels. The CFU per $\mathrm{ml}$ of $X$. axonopodis pv. citri collected was different between samplers. Panels collected the most CFU, probably because of their sampling plane and size: all three samplers were situated in the same sampling zone. The results do suggest variation in sampler efficiency, and/or suggest $X$. axonopodis pv. citri might not be uniformly distributed throughout the spray downwind of infected citrus plants. Because the panels presented the greatest cross-sectional area, they would have the greatest potential to collect both bacterialaden and nonladen droplets in a nonuniform spray. In addition, unlike the panels and funnel samples, the Burkard samples varied in concentration depending on the volume collected, and this is not immediately explicable.

The preliminary results presented here suggest that $X$. axonopodis pv. citri are dispersed in simulated wind-driven spray over at least $10 \mathrm{~m}$ in droplets and confirm the ability of this pathogen to be dispersed several meters from a source of inoculum (22). The size of droplets and the time they remain airborne depend on wind speed, gusts, and the directions of the air movement. The observation that the CFU per $\mathrm{ml}$ dispersed declines with time suggests that even over quite short time periods, the number of bacteria produced from lesions declines, which has been observed previously with isolated leaves $(16,23)$. Wind direction during the experiments appeared to have a comparatively minor effect on the volume of spray collected, so the proportionately greater decline of CFU per $\mathrm{ml}$ dispersed with each experiment repeat suggests that bacterial dispersal is a dynamic process. Of special interest is the fact that $X$. axonopodis pv. citri were collected even when no volume of spray was detected, i.e., they could still be washed off the panel surface. This indicates that they were present in very fine mist and impinged on the sampler surface, even though they were not plentiful enough to coalesce into drops of sufficient volume to flow down the sampler surface into the collection vessel. Other bacteria are reported to be dispersed in aerosol (13), and the presence of bacteria containing droplets of low volume and weight has significant epidemiological implications relative to inoculum dispersal of $X$. axonopodis pv. citri. Such low volume, low weight pathogen-laden droplets presumably can be carried much further downwind in turbulent air without falling out of the air stream due to gravity alone.

Of the many methods available for sampling particulate bioaerosols (14), there are relatively few for sampling droplet-borne inocula. Although simple in design and function, the vertical panels offered a consistent method of capturing bacteria-laden rain splash from canker-infected plants. They have the potential to be useful in studying other splash- and windborne pathogens. Limitations of this technique include the size of the collection vessel, although this would be influenced by rainfall intensity. Sampling times with a 4.5-liter collection vessel were usually limited to 10 to $15 \mathrm{~min}$. Longer collection times would require frequent changes of collection vessels or some other type of modification. While it is possible to relate $X$. axonopodis pv. citri to volume of splash collected, it is not possible to accurately relate bacterial counts to the volume of air sampled. The problem of volumetric quantification arises because bacteria dispersed in splash droplets during wind events are affected by the dynamics of two fluids: water (droplets) and air. Nonetheless, panels provide an effective way of standardizing sampling for windblown splash and can be used to estimate the bacterial concentration in liquid spray, the medium in which the bacteria are actually dispersed. In addition, the panels are very low cost $(\$ 57.00$ per panel), allowing the deployment of a sufficient number of panel samplers at a number of locations downwind from plant canopies.

A thorough knowledge of dispersal characteristics of the citrus canker bacterium will contribute to an understanding of the resulting patterns of infection and the interrelationship between dispersal conditions and infection. This information will contribute to a more rational approach to control strategies based on an understanding of the biological processes. Panels are currently being used in fieldscale investigations of the dispersal of citrus canker bacteria under simulated and natural wind/rain conditions in epidemic areas.

\section{ACKNOWLEDGMENTS}

We thank José Renteria and Russell Sheetz (USDA-APHIS, Edinburg, TX) for help with constructing the equipment and assistance with the experiments.
LITERATURE CITED

1. Butterworth, J., and McCartney, H. A. 1991. The dispersal of bacteria from leaf surfaces by water splash. J. Appl. Bactiol. 7:484-496.

2. Danos, E., Berger, R. D., and Stall, R. E. 1984. Temporal and spatial spread of citrus canker within groves. Phytopathology 74:904-908.

3. Faulwetter, R. C. 1917. Wind-blown rain, a factor in disease dissemination. J. Agric. Res. 10: 639-648.

4. Fitt, B. D. L., Lapwood, D. H., and Dance, S. J. 1983. Dispersal of Erwinia carotovora subsp. atroseptica in splash droplets. Potato Res. 26:123-131.

5. Fitt, B. D. L., McCartney, H. A., and Walklate, P. J. 1989. The role of rain in dispersal of pathogen inoculum. Annu. Rev. Phytopathol. 27:241-270.

6. Gottwald, T. R., Graham, J. H., and Schubert, T. S. 1997. Citrus canker in urban Miami: An analysis of spread and prognosis for the future. Citrus Industry 78:72-78.

7. Gottwald, T. R., Reynolds, K. M., Campbell, C. L., and Timmer, L. W. 1992. Spatial and spatiotemporal autocorrelation analysis of citrus canker epidemics in citrus nurseries and groves in Argentina. Phytopathology 82:843851.

8. Gottwald, T. R., Sun, X., Riley, T., Graham, J. H., Ferrandino, F., and Taylor, E. L. 2002 Geo-referenced spatiotemporal analysis of the urban citrus canker epidemic in Florida. Phytopathology 92:361-377.

9. Gottwald, T. R., Timmer, L. W., and McGuire, R. G. 1989. Analysis of disease progress of citrus canker in nurseries in Argentina. Phytopathology 79:1276-1283.

10. Graham, J. H., and Gottwald, T. R. 1990 Variation in aggressiveness of Xanthomonas campestris pv. citrumelo associated with citrus bacterial spot in Florida citrus nurseries. Phytopathology 80:190-196.

11. Hunter, J. E., and Kunimoto, R. K. 1974 Dispersal of Phytopthora palmivora sporangia by wind-blown rain. Phytopathology 64:202206.

12. Koizumi, M. 1985. Citrus canker: The world situation. Pages 2-7 in: Citrus Canker: An International Perspective. L. W. Timmer, ed. University of Florida, Lake Alfred.

13. Kuan, T.-L., Minsavage, G. V., and Schaad, N. W. 1986. Aerial dispersal of Xanthomonas campestris pv. campestris from naturally infected Brassica campestris. Plant Dis. 70:409. 413.

14. McCartney, H. A., Fitt, B. D. L., and Schmechel, D. 1997. Sampling bioaerosols in plant pathology. J. Aero. Sci. 28:349-364.

15. McInnes, T. B., Gitaitis, R. D., McCarter, S. M., Jaworski, C. A., and Phatak, S. C. 1988. Airborne dispersal of bacteria in tomato and pepper transplant fields. Plant Dis. 72:575579.

16. Pruvost, O., Boher, B., Brocherieux, C. Nicole, M., and Chiroleu, F. 2002. Survival of Xanthomonas axonopodis pv. citri in leaf lesions under tropical environmental conditions and simulated splash dispersal of inoculum. Phytopathology 92:336-346.

17. Roberto, S. R., Gottwald, T. R., Graham, J. H. and Riley, T. 2001. Xanthomonas axonopodis pv. citri aerosol production in Miami, Florida. Sum. Phytopathol. 27:56-60.

18. Schubert, T. S., Rizvi, S. A., Sun, X., Gottwald, T. R., Graham, J. H., and Dixon, W. N. 2001. Meeting the challenge of eradicating citrus canker in Florida - Again. Plant Dis. 85:340-356.

19. Serizawa, S. 1981. Recent studies on the behavior of the causal bacterium of the citrus canker. Proc. Int. Soc. Citric. 1981. 1:395397.

20. Serizawa, S., Inoue, K., and Goto, M. 1969 Studies on citrus canker I. Dispersal of the cit- 
rus canker organism. Bull. Schizuoka Pref. Citrus Exp. Stn. 8:81-85.

21. Silas, J. C., Harrison, M. A., Carpenter, J. A., and Floyd, J. B. 1986. Comparison of particulate air samplers for detection of airborne Aspergil- lus flavus spores. J. Food Prot. 49:236-238

22. Stall, R. E., Miller, J. W., Marco, G. M., and deEchenique, B. I. C. 1980. Population dynamics of Xanthomonas citri causing cancrosis of citrus in Argentina. Proc. Fla. St. Hortic.
Soc. 93:10-14.

23. Timmer, L. W., Gottwald, T. R., and Zitko, S. E. 1991. Bacterial exudation from lesions of Asiatic citrus canker and citrus bacterial spot. Plant Dis. 75:192-195. 